\title{
Geochemical Analysis of Ilaro-Papalanto Highway Subgrade
}

\author{
${ }^{1}$ Apata, A. C. and ${ }^{2 *}$ Adedokun, S. I. \\ ${ }^{1,2}$ Department of Civil and Environmental Engineering, University of Lagos, Yaba, Lagos, Nigeria. \\ *Corresponding E-mail: siadedokun@unilag.edu.ng
}

\begin{abstract}
In this study, the geochemical analysis of the subgrade at different locations of Ilaro-Papalanto highway was conducted using Atomic Absorption Spectrometry (AAS) and X-Ray Diffractometry (XRD). The predominant oxides present in both soil samples are Silicon Oxide (40\% - 45\%) and Aluminium Oxide (31\% - 34\%), and the average silica content of Ilaro and Papalanto are 45.71\% and $40.71 \%$ respectively, which implies that Ilaro soil sample is more chemically inert and structurally stable than Papalanto soil samples. The average sesquioxide content of Papalanto (36.27\%) is higher than that of Ilaro (32.87\%), while the silica sesquioxide ratio (SSR) of Papalanto (1.12\%) is less than that of Ilaro (1.39\%), therefore both soil samples are in advanced stage of weathering but Papalanto soil is more lateritic than Ilaro. Geochemical analysis using XRD indicated the presence of three clay minerals (Kaolinite, Illite and traces of Montmorrrilonite) and one major non-clay mineral, Quartz. The average proportion of Kaolinite in the soil samples are 9\% (Ilaro) and 28\% (Papalanto), but the average values of Quartz are $62 \%$ and $69 \%$ for Ilaro and Papalanto, respectively. The higher proportion of sesquioxide and Kaolinite from Papalanto samples is an indication of more failures observed in the region.
\end{abstract}

Keywords: Geochemical analysis, X-ray diffraction, Clay minerals, Quartz and Lateritic soil.

\section{Introduction}

Deficiencies in the properties of soil can substantially influence the stability and serviceability potential of the intending civil engineering structure. Laterite, which is a soil group, is formed under weathering systems as a product of laterization processes such as decomposition of ferroalumino-silicate minerals, leaching of the combined silica and base; and the permanent deposition of sesquioxide within the soil profiles (Odell, 2012, Adedokun et al., 2018, 2019a). Gidigasu (1976), Akpokodje (2001) and Oghenekaro et al. (2014) stated that lateritic soils are products of intense weathering which are devoid of gravel-sized components and occur under tropical climatic condition leading to the accumulation of hydrated oxides of iron and aluminium. Hence there could be considerable variations in geotechnical features of lateritic soils within quite short distances (Adeyemi and Wahab, 2008).

The deficiency in morphological properties of lateritic soil can limit its suitability as construction material, such soil is termed problematic soil because they have low strength, high compressibility and settlement (Oluremi et al., 2016). The variation in the morphological properties of engineering soil which also influences the geotechnical properties of soils is determined by the content of sesquioxides, level of weathering, extent of desiccation in the soil, fine content, clay mineralogy and clay-size content. This makes the definition of engineering soil based on the ratios of silica $\left(\mathrm{SiO}_{2}\right)$ content to sesquioxides $\left(\mathrm{Fe}_{2} \mathrm{O}_{3}+\mathrm{Al}_{2} \mathrm{O}_{3}\right)$ content to be more acceptable. The ratios are less than 1.33 for laterites, between 1.33 and 2.0 for lateritic soils and greater than 2.0 for non-lateritic soils (Bell, 1993; Adedokun and Oluremi, 2019; Adedokun et al.2019b). Several laterite gravels and pisoliths that are commonly good for gravel roads occur in tropical countries of the world, including Nigeria (Osinubi and Bajeh, 1994). Conversely, there are several instances where 
laterite may contain significant quantity of clay minerals (Kaolinite, Illite and traces of Montmorrrilonite), thereby becomes poor, that its strength and stability cannot be guaranteed under load especially in the presences of moisture.

The presence of swelling clay minerals in lateritic soils greatly influenced its overall performance. As swelling clays get wet, they absorb water molecules and expand; conversely, as they dry, they shrink, leaving large voids in the soil. Swelling clays can control the behavior of virtually any type of soil if the percentage of clay is more than about 5 percent by weight. Soils with smectite clay minerals, such as montmorillonite, exhibit the most profound swelling properties (NBRRI, 1983). The presence of these clay minerals in foundation materials are the major indicators of problems in the fundamental properties of soil such as gradation, consistency, compressibility, strength, permeability, swell potential and workability (Amadi, 2010). In many instances, these had led to failures of highways and other civil engineering structures.

$\mathrm{X}$-ray diffraction analysis (XRD) is a technique used in materials science to determine the crystallographic structure of a material. XRD works by irradiating a material with incident X-rays and then measuring the intensities and scattering angles of the X-rays that leave the material (Townsend, 1970). A primary use of XRD analysis is the identification of materials based on their diffraction pattern. As well as phase identification, XRD also yields information on how the actual structure deviates from the ideal one, owing to internal stresses and defects.

Since clay mineralogy has been found to affect engineering properties of soils in general (Bell, 1993; Adedokun and Oluremi, 2019), it is imperative to investigate the clay minerals of the studied soil accurately and make useful interpretation of the engineering test results. This study therefore carried out the geochemical analyses of Ilaro-Papalanto Highway Subgrade to assess the causes of failures at different sections of the highway.

\section{Materials and Methods}

The relative contents of the major oxides in the investigated soil samples were determined by the Atomic Absorption Spectrometry (AAS) and gravimetric method at the Department of Chemistry, University of Lagos. Powdered samples of soil from eight different locations identified as locations 1 to 8 (the first six sample locations were from Papalanto and the last two sample locations from Ilaro) were examined using X-ray diffraction (XRD) analysis. The soil samples were pulverized into powder whose diameter were in the range of microns of less than $<5 \mathrm{~mm}$ in diameter. The X-ray diffractometer test was performed with the Philips PW 1011 model diffractometer at the National Steel Centre, Kaduna.

X-ray diffraction tests were carried out by placing a powdered clay sample (samples passing BS sieve No. 200) in a beam of x-rays, which is diffracted through characteristic angle, by crystal lattice of the clay (Johnson and Maxwell, 1981). To reinforce each other, the reflected x-rays in the adjacent layer must be in the same phase. This will be so if the path difference is equal to a whole number of wavelengths. Using Bragg's law as shown in equation 1.

$\mathrm{d}=\frac{n \lambda}{2 \sin \theta}$

where

$n=$ a constant $=1$ (for practical purposes) 
$\lambda=$ wavelength of the target $x-$ ray

$\theta=$ the angle of each peak concerned

$\mathrm{d}=$ computed interplanar spacing of the mineral, and is given by:

The calculated interplanar spacing on each diffractogram was compared with standard values established by Carrol (1971). The percentage composition of each clay mineral is given by equation 2 .

$\mathrm{P}(\%)=\mathrm{Ac} / \sum \mathrm{Ai}$

Where,

Ac $=$ Area of strongest peak of the clay mineral

$\sum \mathrm{A} \mathrm{i}=$ Sum of area of storngest peak of all identified minerals.

\section{Results and Discussion}

\section{Oxide composition by atomic absorption spectroscopy}

Table 1 presents the result of the oxide composition of the subgrade soil samples taken from Ilaro and Papalanto by Atomic Absorption Spectroscopy. The predominant oxides in both soil samples are Silicon Oxide $\left(\mathrm{SiO}_{2}\right)$ and Aluminium Oxide $\left(\mathrm{Al}_{2} \mathrm{O}_{3}\right)$. The Silica content of Ilaro $(45.71 \%)$ is higher than that of Papalanto (40.71\%), while the Aluminium Oxide content of Ilaro (31.40\%) is lower than that of Papalanto (34.42\%). Iron Oxide and Calcium Oxide are very low. The predominant metals present in the soil samples are Copper, Manganese and Iron. The average Sesquioxide content and silica sesquioxide ratio (SSR) are $32.87 \%$ and 1.39 for Ilaro and $36.27 \%$ and $1.12 \%$ for Papalanto respectively.

\section{Silica content}

Silica $\left(\mathrm{SiO}_{2}\right)$, is chemically inert and structurally stable. The proportion of $\mathrm{SiO}_{2}$ in any soil is therefore a measure of its inertness and structural stability (Meshida and Akanbi, 2007). The more the quantity of $\mathrm{SiO}_{2}$ in a soil, the more non-lateritic it becomes, and the more the soil becomes free from the problems associated with Sesquioxide (clay mineral). Thus, soil that contains such material is able to resist traffic load and surface deformations (Akanbi, 2008). The average silica content of Ilaro (45.71\%) is more than that of Papalanto (40.71\%). Therefore, Ilaro soil is more chemically inert and structurally stable than Papalanto soil (see Table 1)

\section{Sesquioxide content}

The Sesquioxide content is represented by the total percentage of ferric and alumina $\left(\mathrm{Fe}_{2} \mathrm{O}_{3}+\right.$ $\mathrm{Al}_{2} \mathrm{O}_{3}$ ) in the soil. The Sesquioxide coating in lateritic soils inhibit the normal surface activity of clay minerals/particles to such an extent that plasticity, shrinkage and swelling parameters are inaccurately obtained when tested in the laboratory. The silica Sesquioxide ratio for each sample is shown in Table 1. The average sesquioxide content of Papalanto is $36.27 \%$. The average sesquioxide content of Ilaro is $32.87 \%$. Since the average sesquioxide content of Papalanto $(36.27 \%)$ is higher than that of Ilaro (32.87\%), the sesquioxide related problem of lateritic soils is more pronounced in Papalanto than with Ilaro. 


\section{Ferric iron content.}

The average Ferric Iron content of Papalanto is $1.85 \%$ while that of Ilaro is $1.47 \%$, Table 1. Ferric Iron is an important cementing agent in lateritic soils. It is responsible for the formation of weak iron bond that aggregates fine particles to coarse particles (Townsend, 1970; Gidigasu, 1976). Hence, Papalanto soil may show higher strength than Ilaro soil when dry due to the higher ferric content and bond. The bond may not be durable, it breaks down in the presence of water (Akanbi, 2008).

\section{Silica sesquioxide ratio (SSR)}

Silica Sesquioxide ratio (SSR) is a measure of the degree of lateritization of a soil. The lower the ratio, the higher the degree of lateralization, and the more lateritic the soil is (Gidigasu, 1976). The ratios are less than 1.33 for laterites, between 1.33 and 2.0 for lateritic soils and greater than 2.0 for non-lateritic soils (Townsend, 1970; Bell, 1993; Adedokun and Oluremi, 2019; Adedokun et al. 2019b). The SSR of Ilaro soil is $1.39 \%$ while that of Papalanto is $1.12 \%$. Since the SSR ratio of Papalanto is less than that of Ilaro, the implication is that Papalanto soil is more lateritic than Ilaro and has gone through a higher degree of lateralization (Bell, 1993).

Table 1: Oxide Composition of Studied Soil Samples

\begin{tabular}{|c|c|c|}
\hline Chemical Oxides (\%) & Ilaro & Papalanto \\
\hline $\mathrm{SiO}_{2}$ & 45.71 & 40.71 \\
\hline $\mathrm{Al}_{2} \mathrm{O}_{3}$ & 31.40 & 34.42 \\
\hline $\mathrm{Fe}_{2} \mathrm{O}_{3}$ & 1.47 & 1.85 \\
\hline $\mathrm{CaO}$ & 0.03 & 0.05 \\
\hline $\mathrm{MgO}$ & 0.05 & 0.04 \\
\hline $\mathrm{Na}_{2} \mathrm{O}$ & 0.06 & 0.05 \\
\hline $\mathrm{K}_{2} \mathrm{O}$ & 0.54 & 0.56 \\
\hline Loi & 16.66 & 14.22 \\
\hline $\mathrm{SiO}_{2} /\left(\mathrm{Al}_{2} \mathrm{O}_{3}+\mathrm{Fe}_{2} \mathrm{O}_{3}\right)$ & 1.39 & 1.12 \\
\hline Sesquioxide content $\left(\mathrm{Fe}_{2} \mathrm{O}_{3}+\mathrm{Al}_{2} \mathrm{O}_{3}\right)$ & 32.87 & 36.27 \\
\hline
\end{tabular}

\section{Mineralogical Characterization by X-Ray Diffraction (XRD)}

Table 2 shows the mineral compositions of the subgrade samples from X-ray diffraction techniques at different locations (1-8) of Ilaro-Papalanto highway, while Table 3 presents the summary of the mineralogical compositions at different locations of the highway. Results from Tables 2-3 and Figure 1 showed the presence of clay minerals and non-clay mineral (quartz) in the soil samples.

For location 1 (Subgrade 1), Figure 1 highlighted the most prominent minerals in the XRD spectrum, and the main minerals identified in Table 2 are Quartz, Nylon which is a family of Kaolinite and Zinc Aluminum nitrous hydrate. The most prominent minerals in the XRD spectrum for location 2 (Subgrade 2) as shown Figure 1 and Table 2 are identified as Quartz, Kaolinite and Aluminum silicon, while the main minerals identified in location 3 are Quartz, dickite and Kaolinite. At locations 4, 5 and 6, the most prominent minerals are Quartz and Kaolinite while it is 
Quartz and dickite at location 7. For location 8, the main minerals identified are Quartz, dickite, neotocita, calcium nickel diutorium and Kaolinite.

The analysis of these results showed that Quartz is the most prominent mineral in subgrade followed by kaolinite. The presence of kaolinite, which is clay mineral is well reflected from sample locations 2, 3, 4, 5 and 6 that are from Papalanto section of the road while location 8 from Ilaro section has some traces of kaolinite. The prominent occurrence of kaolinite in Papalanto account for more failure in the region. Therefore, the stabilization of the soil is needed. The average weight of Quartz in the samples in the diffactogram as presented in Table 3 is about $62 \%$ for Ilaro and $69 \%$ for Papalanto in all the examined subgrade soil samples. The samples are mostly of detrital nature, deposited as intergranular matrix. The fine-grained soil material (Lateritic clay) are porous and permeable, with most of the pore volume in the form of primary intergranular pores. There existed rare Secondary pores which are normally due to partial dissolution of feldspar grains.

\section{Effect of clay minerals in the soil mineralogy}

The three major minerals are Kaolinite $\left(\mathrm{Al}_{4} \mathrm{Si}_{4} \mathrm{O}_{10}(\mathrm{OH})_{8}\right)$, Illite $\left(\mathrm{Al}_{4} \mathrm{Si}_{4} \mathrm{O}_{10}(\mathrm{OH})_{8} \cdot \mathrm{nH}_{2} \mathrm{O}\right)$ and Montmorillonite $\left(\mathrm{Al}_{4} \mathrm{Si}_{4} \mathrm{O}_{10}(\mathrm{OH})_{8} \cdot \mathrm{nH}_{2} \mathrm{O}\right)$ with interlayer spacing of $7.1 \mathrm{~A}^{0}\left(=7.1 \mathrm{x} 10^{-7} \mathrm{~mm}\right), 10 \mathrm{~A}^{0}$ and $15 \mathrm{~A}^{0}$ respectively (Smith and Smith, 2000). The effect of clay minerals is to impact a net negative charge on lateritic soil. The negative charge attracts the hydrogen polar end of water, and makes the soil effectively hygroscopic (NBRRI, 1983). When a soil that contains an appreciable proportion of clay comes in contact with water, water penetrates and is accommodated into the interlayer spacing of the clay minerals. Consequent upon this, the soil swells up and becomes soft, losing its strength and bearing capacity. On the other hand, when water is lost from the interlayer spacing of clay minerals, the soil shrinks and cracks severely (NBRRI, 1983). Kaolinite is the most abundant clay mineral in the soil. It has the least swelling and shrinkage tendency. The average proportion of Kaolinite in the soil samples are 9\% (Ilaro) and $28 \%$ (Papalanto). This indicates that soil samples from Papalanto have tendency to swell and shrink than Ilaro.

Table 2: Mineral Compositions of the subgrade samples at different locations of Ilaro-Papalanto highway

\begin{tabular}{|c|c|c|c|c|c|c|c|c|}
\hline Location & Peak & $2 \theta$ & $\begin{array}{l}\text { Composition } \\
(\%)\end{array}$ & $\begin{array}{l}\text { Chemical } \\
\text { formula }\end{array}$ & Compound name & Structure & Colour & $\begin{array}{l}\text { Position } \\
(h, k, l)\end{array}$ \\
\hline \multirow{3}{*}{$\begin{array}{c}1 \\
(2.5 \mathrm{~km})\end{array}$} & 1933 & 27 & 80 & $\mathrm{a}^{\prime}-\mathrm{SiO}_{2}$ & Quartz-a' low & Tetragonal & - & $0,2,3$ \\
\hline & 324 & 21 & 29 & $\left(\mathrm{C}_{11} \mathrm{H}_{2} \mathrm{ON}_{2} \mathrm{O}_{2}\right) \mathrm{n}$ & Nylon 65 & - & - & $2,0,0$ \\
\hline & 277 & 50 & 14 & $\mathrm{Al}_{2} \mathrm{Si}_{2} \mathrm{O}_{5}(\mathrm{OH})_{4}$ & Kaolinite-1A & Triclinic & White & $2,2,3$ \\
\hline \multirow{4}{*}{$\begin{array}{c}2 \\
(6.0 \mathrm{~km})\end{array}$} & 1245 & 28 & 56 & $\mathrm{a}^{\prime}-\mathrm{SiO}_{2}$ & Quartz-a' low & Tetragonal & - & $1,1,3$ \\
\hline & 439 & 21 & 32 & $\mathrm{Al}_{2} \mathrm{Si}_{2} \mathrm{O}_{5}(\mathrm{OH})_{4}$ & Kaolinite-1A & Triclinic & White & $1,1,1$ \\
\hline & 206 & 41 & 16 & $\mathrm{Si}_{1.8} \mathrm{Al}_{0.2} \mathrm{O}_{1.2} \mathrm{~N}$ & $\begin{array}{l}\text { Aluminium silicon } \\
\text { O.. }\end{array}$ & - & - & $1,3,3$ \\
\hline & 203 & 50 & 09 & $\mathrm{Mg}-\mathrm{Fe}-\mathrm{Al}-\mathrm{Si}$ & Clinoclore & Monoclinic & Oblique & $2,2,4$ \\
\hline \multirow{3}{*}{$\begin{array}{c}3 \\
(10.0 \mathrm{~km})\end{array}$} & 2982 & 28 & 51 & $\mathrm{SiO}_{2}$ & Quartz & Hexagonal & - & $1,1,3$ \\
\hline & 246 & 55 & 40 & $\mathrm{Al}_{2} \mathrm{Si}_{2} \mathrm{O}_{5}(\mathrm{OH})_{4}$ & Dickite -2MI & Monoclinic & White & $-1,3,7$ \\
\hline & 235 & 21 & 19 & $\mathrm{Al}_{2} \mathrm{Si}_{2} \mathrm{O}_{5}(\mathrm{OH})_{4}$ & Kaolinite & Triclinic & White & $1,1,1$ \\
\hline \multirow{3}{*}{$\begin{array}{c}4 \\
(13.0 \mathrm{~km})\end{array}$} & 1607 & 27 & 83 & $\mathrm{a}^{\prime}-\mathrm{SiO}_{2}$ & Quartz & Hexagonal & - & $1,1,4$ \\
\hline & 870 & 21 & 37 & $\mathrm{Al}_{2} \mathrm{Si}_{2} \mathrm{O}_{5}(\mathrm{OH})_{4}$ & Kaolinite & Triclinic & White & $1,0,3$ \\
\hline & 266 & 60 & 20 & $\mathrm{Na}_{0.33} \mathrm{TaS}_{2} \mathrm{O}_{0.65}$ & - & - & - & $0,-2,2$ \\
\hline 5 & 1659 & 29 & 78 & $\mathrm{SiO}_{2}$ & Quartz & Hexagonal & - & $0,-1,1$ \\
\hline$(16.0$ km) & 496 & 21 & 37 & $\mathrm{Al}_{2} \mathrm{Si}_{2} \mathrm{O}_{5}(\mathrm{OH})_{4}$ & Kaolinite & Triclinic & White & $1,0,0$ \\
\hline
\end{tabular}


Geochemical Analysis of Ilaro-Papalanto Highway Subgrade

\begin{tabular}{|c|c|c|c|c|c|c|c|c|}
\hline & 375 & 68 & 18 & $\mathrm{Na}_{0.33} \mathrm{TaS}_{2} \mathrm{O}_{0.65}$ & - & - & - & $-3,1,2$ \\
\hline & 2293 & 29 & 68 & $\mathrm{SiO}_{2}$ & Quartz & Tetragonal & - & $3,1,4$ \\
\hline 6 & 1200 & 51 & 29 & $\mathrm{Al}_{2} \mathrm{Si}_{2} \mathrm{O}_{5}(\mathrm{OH})_{4}$ & Kaolinite-1A & Triclinic & White & $4,4,4$ \\
\hline$(18.0 \mathrm{~km})$ & 357 & 60 & 14 & $\mathrm{Cu}_{0.33} \mathrm{Al}_{0.75} \mathrm{Zn}_{1.8}$ & $\begin{array}{c}\text { Copper Zinc } \\
\text { Alumina } \\
\end{array}$ & - & - & $5,1,1$ \\
\hline \multirow{5}{*}{$\begin{array}{c}7 \\
(19.0 \mathrm{~km})\end{array}$} & 1407 & 29 & 67 & $\mathrm{SiO}_{2}$ & Quartz & Tetragonal & - & $5,0,3$ \\
\hline & 400 & 21 & 31 & $\mathrm{Al}_{2} \mathrm{Si}_{2} \mathrm{O}_{5}(\mathrm{OH})_{4}$ & Dickite -2MI & Monoclinic & White & $1,0,1$ \\
\hline & 287 & 69 & 25 & $\mathrm{~K}-\mathrm{Al}-\mathrm{Fe}-\mathrm{PO}_{4}$ & Potassium & Almarudite & - & $-3,1,2$ \\
\hline & 278 & 42 & 19 & $\mathrm{Al}_{2} \mathrm{Si}_{2} \mathrm{O}_{5}(\mathrm{OH})_{4}$ & $\begin{array}{l}\text { aluminium hydrate } \\
\text { Nacrite-1Md }\end{array}$ & Tetrahedral & Yellow & $-2,-1,2$ \\
\hline & 227 & 50 & 10 & $\mathrm{Al}_{0.29} \mathrm{Ga}_{0.71} \mathrm{PO}_{4}$ & $\begin{array}{l}\text { Aluminium gallium } \\
\text { phosphate }\end{array}$ & - & - & $3,0,7$ \\
\hline \multirow{6}{*}{$\begin{array}{c}8 \\
(19.5 \mathrm{~km})\end{array}$} & 735 & 21 & 57 & $\mathrm{SiO}_{2}$ & Quartz & Tetragonal & - & $-4,0,4$ \\
\hline & 555 & 28 & 42 & $\mathrm{Al}_{2} \mathrm{Si}_{2} \mathrm{O}_{5}(\mathrm{OH})_{4}$ & Dickite -2MI & Monoclinic & White & $-6,0,2$ \\
\hline & 262 & 69 & 37 & $(\mathrm{Mn}, \mathrm{Mg}, \mathrm{Fe}) \mathrm{S}$. & Neotocite & Octahedral & $\begin{array}{c}\text { Dark } \\
\text { brown }\end{array}$ & $0,3,2$ \\
\hline & 255 & 42 & 19 & $\mathrm{CaNiO}_{3}$ & $\begin{array}{c}\text { Calcium nickel } \\
\text { deuterium }\end{array}$ & - & - & $-4,2,4$ \\
\hline & 214 & 51 & 18 & $\mathrm{Na}_{0.3} \mathrm{Al}_{4} \mathrm{Si}_{5} \mathrm{O}_{15}$ & Kaolinite-Montmori & - & - & $6,2,3$ \\
\hline & 213 & 38 & 13 & $\mathrm{Dy}_{3} \mathrm{Mn}_{3} \mathrm{SiGa}_{2}$ & $\begin{array}{l}\text { Dysprosium } \\
\text { manganese }\end{array}$ & - & - & $-2,2,3$ \\
\hline
\end{tabular}

$\theta=$ angle of diffraction

Table 3: Summary of Mineralogical Composition of the Selected Soil samples by X-Ray Diffraction

\begin{tabular}{cccccc}
\hline Location & Site & $\begin{array}{c}\text { Kaolinite } \\
(\mathbf{\%})\end{array}$ & Illite (\%) & $\begin{array}{c}\text { Montmorrilonite } \\
\mathbf{( \% )}\end{array}$ & $\begin{array}{c}\text { Quartz } \\
(\mathbf{\%})\end{array}$ \\
\hline 1 & Papalanto & 14 & 0 & 0 & 80 \\
2 & Papalanto & 32 & 0 & 0 & 56 \\
3 & Papalanto & 19 & 0 & 0 & 51 \\
4 & Papalanto & 37 & 0 & 0 & 83 \\
5 & Papalanto & 37 & 0 & 0 & 78 \\
6 & Papalanto & 29 & 0 & 0 & 68 \\
7 & Ilaro & 0 & 0 & 0 & 67 \\
8 & Ilaro & 18 & 0 & 0 & 57 \\
\hline
\end{tabular}



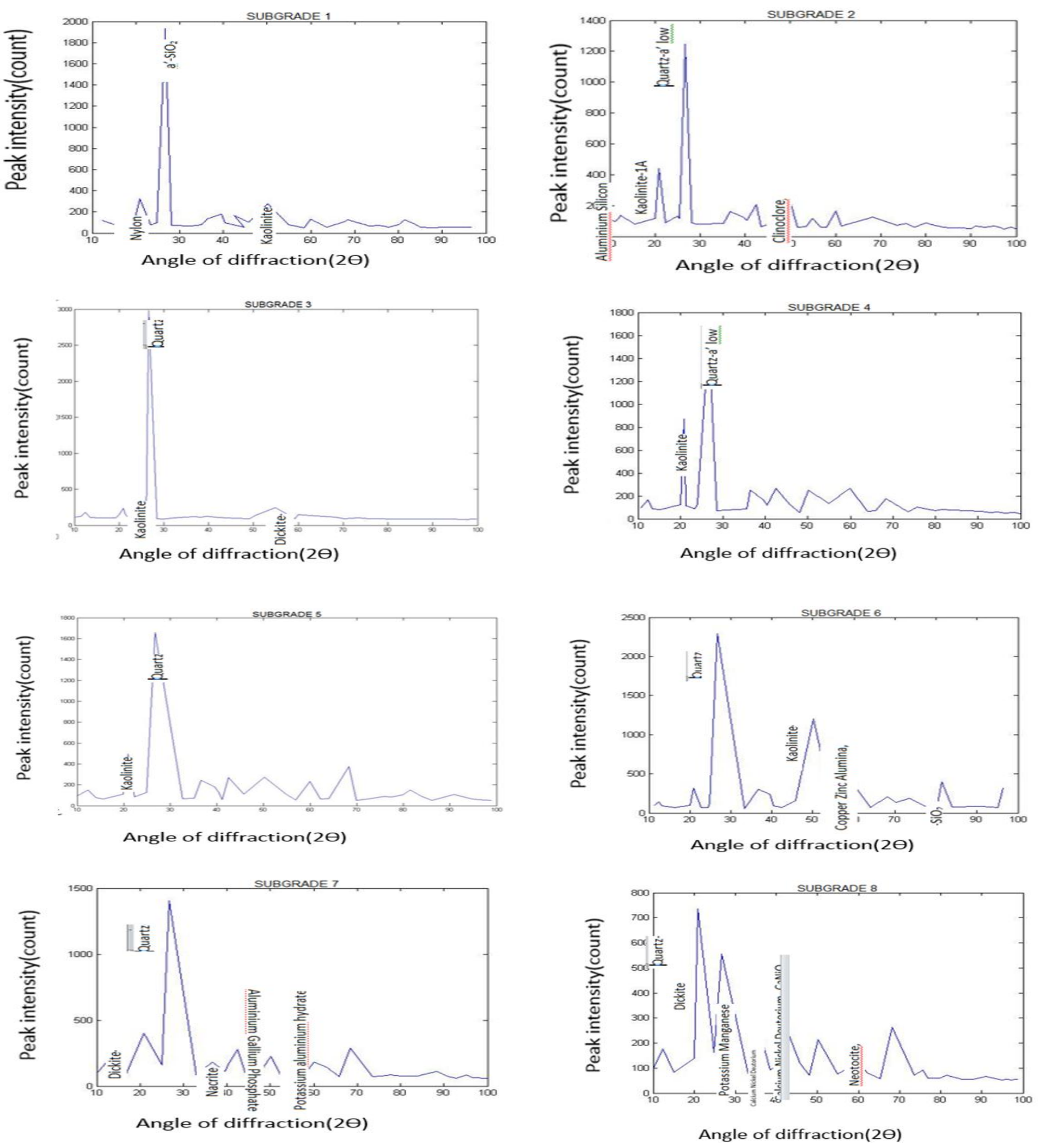

Figure 1: X-Ray Diffraction test results for subgrade at various locations of highway 


\section{Conclusion}

The following conclusions were drawn from the results of the geochemical tests conducted on Ilaro-Papalanto highway subgrade.

i. The results of the Atomic Absorption Spectroscopy tests showed that average silica content of Ilaro is slightly higher than that of Papalanto, and this implies that Ilaro soil sample is more chemically inert and structurally stable than Papalanto soil samples. In addition, the silica sesquioxide ratio (SSR) ratio of Papalanto is less than that of Ilaro, therefore both soil samples are in advanced stage of weathering but Papalanto soil is more lateritic than Ilaro. This may likely be responsible for more failures in the Papalanto region.

ii. The geochemical analysis using X-ray diffractometry showed that Quartz is the most prominent mineral followed by kaolinite. The presence of kaolinite which is clay mineral is well reflected from Papalanto section of the road while Ilaro section has some traces of kaolinite. The average proportion of Kaolinite in the soil samples at the Ilaro section of the road is significantly lower than that of Papalanto section. This indicates that soil samples from Papalanto have tendency to swell and shrink more than those of Ilaro. The prominent occurrence of kaolinite in Papalanto account for more failures observed in the region.

\section{References}

Adedokun, S.I. Oluremi, J.R. Adekilekun, N. Adeola, V. (2018). Effects of Cement Kiln Dust on the Geotechnical Properties of Clay in Ede, South-Western, Nigeria. LAUTECH Journal of Civil and Environmental Studies, 1: 14-20.

Adedokun, S.I. Ganiyu, A.A. Adedokun, M.A (2019a). Effect of marble dust and steel slag on consistency limits and compaction characteristics of lateritic soil, IOP Conference Series: Materials Science and Engineering, 527 (2019a) 1-12. doi:10.1088/1757$899 \mathrm{X} / 527 / 1 / 012026$.

Adedokun, S.I. Oluremi, J.R. Obebe, D.S. (2019b). Effects of Glass Fines on the Geotechnical Properties of Cement Stabilized Lateritic Soil. International Journal of Engineering Research in Africa, 45: 42-52. doi: 10.4028/www.scientific.net/jera.45.42.

Adedokun, S.I. Oluremi, J.R. (2019). A review of the stabilization of lateritic soils with some agricultural waste products. Annals of Faculty Engineering Hunedoara - International Journal of Engineering 17(2): 63 -74. http://annals.fih.upt.ro/ANNALS-2019-2.html

Adeyemi,G.O, and Wahab, K.A. (2008). Variability in the Geotechnical Properties of a Lateritic Soil from South Western Nigeria. Bull. Eng. Geol. Environ, 67(4) (2008) 579-584. 
Akanbi E.O. (2008). A Geotechnical Assessment of 'Coastal Plain Sands' of South Western Nigeria as a Subgrade and Highway Construction Material; Unpublished Ph.D. thesis, Department of Civil Engineering, University of Lagos.77- 113.

Amadi, A.A. (2010). Evaluation of Changes in Index Properties of Lateritic Soil with Fly ash. Leonardo Electronic Journal of Practice and Tech (LEJPT), 9(17) (2010) 69 - 78.

Akpokodje, E.G. (2001) Introduction to Engineering Geology. Pam Unique Publishing Co. Ltd., Port Harcourt, 180-181.

Bell, F.G. (1993). Engineering treatment of soils, E \& FN Spon, London

Carol, D. (1971). 'Clay minerals: A guide to their X-ray identification' Geol. Soc. Am. Special paper 126.

Odell, A.D. (2012). Modification of Lateritic Soil Treated with SawDust ash using British Standard Heavy Compactive Effort. Available in https://www.scribd.com/doc/110826616/Complete-Work.

Oluremi, J.R., Osuolale, O.M., Adeoye, T.T. and Abiola, A.A. (2016) Strength Development in Lateritic Soil Stabilised with Coconut Shell Ash for Highway Pavement Construction, Innovative Systems Design and Engineering, 7 (11): 49-56.

Gidigasu M.D. (1976). Laterite soil Engineering, Pedogenesis and Engineering Principles. Elsevier Scientific Publishing Company Amsterdam Oxford New York.

Johnson, W. M. and Maxwell, J. A. (1981). 'Rock and mineral analysis' (2 ${ }^{\text {nd }}$ ed.), John Wiley and Sons.

Meshida, E. A. and Akanbi (2007). 'Effects of regarding on properties of Coastal Plain Sands' NSE Technical Transactions, 42(2): 18-20.

NIBBRI (1983). 'Engineering properties of black cotton soils of Nigeria and related Pavement design'. Nigerian Building and Road Research Institute, Research Paper, 1- 20

Oghenero, A, Akpokodje, E.G. and Tse, A.C. (2014). Geotechnical Properties of Subsurface Soils in Warri, Western Niger Delta, Nigeria. Journal of Earth Sciences and Geotechnical engineering, 4, 89-102.

Osinubi, K.J. and Bajeh, I. (1994). Bituminous stabilization of laterite. Spectrum Journal, 1(2): 104-112.

Smith, G.N., and Smith, F.G.N. (2000) 'Elements of Soil Mechanics. (7 ${ }^{\text {th }}$ ed) Blackwell Science Ltd, USA.

Townsend, F.C. (1970). The Influence of Sesquioxides on Some Physico-Chemical and Engineering Properties of a Lateritic Soil, PhD Thesis, Department of Civil Engineering, Oklahoma State University, USA. 